\title{
Geopolymers as active capping materials for in situ remediation of metal(loid)-contaminated lake sediments
}

Johanna Kutunivaa,b, Jari Mäkinen ${ }^{c}$, Tommi Kauppila $^{c}$, Anssi Karppinen ${ }^{d}$, Seppo Hellsten ${ }^{d}$, Tero Luukkonen ${ }^{e, f}$ and Ulla Lassi ${ }^{\text {b }}$

a. University of Oulu, Kerttu Saalasti Institute Pajatie 5, FI-85500 Nivala, Finland

b. University of Oulu, Research Unit of Sustainable Chemistry, FI-90014, Finland

c. Geological Survey of Finland, P.O. Box 1237, Fl-70211 Kuopio, Finland

d. Freshwater Centre, Finnish Environmental Institute, FI-90014 Oulu, Finland

e. Kajaani University of Applied Sciences, Kuntokatu 5, FI-87100, Kajaani, Finland

f. University of Oulu, Fibre and Particle Engineering Research Unit, FI-90014, University of Oulu, Finland

Corresponding author: Johanna Kutuniva (johanna.kutuniva@oulu.fi)

\begin{abstract}
Metal(loid) contamination in sediments is a widespread environmental issue. Sediments act normally as metal(loid) sinks, but if chemical conditions (such as $\mathrm{pH}$ or redox potential) change, they can become sources of secondary pollution. Consequently, various strategies for both in and ex situ remediation of contaminated sediments have been developed. One promising method is active capping, which involves the injection of adsorbents as a layer on the sediment surface or the mixing of adsorbents within the sediment. Adsorbents decrease the bioavailability of metal(loid)s. In the present work, the suitability of alkali-activated blast-furnace-slag, metakaolin geopolymer, and exfoliated vermiculite were evaluated for in situ stabilization of two metal(loid)-contaminated lake sediments through laboratory-scale experiments. The results indicated that adsorbent
\end{abstract}


amendments had metal(loid)-specific performance: alkali-activated blast-furnace slag was suitable for $\mathrm{Al}, \mathrm{Cu}, \mathrm{Fe}$, and $\mathrm{Ni}$; metakaolin geopolymer for $\mathrm{Cu}, \mathrm{Cr}$ (total), and $\mathrm{Fe}$; and vermiculite for $\mathrm{Al}$ and $\mathrm{Zn}$. None of the materials could stabilize $\mathrm{Ba}, \mathrm{Sr}$, or Ti. Furthermore, the amendments performed differently in two different lake sediments, implying that the effectiveness of the amendments needs to be confirmed on a case-by-case basis.

Keywords: active capping; alkali-activation; geopolymer; remediation; sediment; vermiculite

\section{Introduction}

Metal and metalloid contamination in soils and sediments is a widespread environmental issue (Klavinš et al., 2000). Some metal(loid)s can be potentially toxic for flora and fauna if they exceed certain threshold levels, and since they are non-biodegradable, they accumulate in the food chain. Mining activities, especially from unsustainably closed mines (González-Fernández et al., 2018), and accidentally released un-treated effluents or tailings (Cagnin et al., 2017; Saup et al., 2017) represent a major point source of metal(loid) contamination to water bodies and thus affect sediments in the long term (Jain and Das, 2017).

In aquatic systems, metal(loid)s can occur as dissolved, colloids, suspensions, or adsorbed in sediments. In fact, when conditions are favorable, sediments can bind to more than $99 \%$ of aqueous metal(loid)s (Salomons and Stigliani, 2012). Sediments therefore act as important sinks. However, changes in chemical conditions (i.e., $\mathrm{pH}$ value or reduction-oxidation potential) can result in partial re-dissolution of the bound metal(loid)s, and thus, sediments can act also as secondary sources of pollution (Simpson et al., 2000; Zoumis et al., 2001). In addition, hydrological factors affect the dynamics of metal(loid) stability in the sediments; for instance, bioturbation caused by benthic organisms, advection, diffusion, or underflows can result in metal(loid) re-suspension (Jacobs and Förstner, 2001). 
Natural processes are frequently inadequate to cope with elevated metal(loid) loading, and there is therefore a need for remediation measures. In ex situ treatment, contaminated sediment is dredged and treated off-site using different techniques (Mulligan et al., 2001). However, dredging is costly and causes significant disturbance to benthic fauna and the whole ecosystem (Rasheed and Balchand, 2007). In situ treatment, on the other hand, is a less disruptive method. It involves injection of either inert materials (such as sand, clay, or crushed stone on geotextiles) or active capping materials (adsorbent) on the sediment surface or mixing of these materials within the sediment (Koschorreck et al., 2007; Mohan et al., 2000; Palermo et al., 1998; Zhang et al., 2016). The aim of passive and active capping is to decrease the metal bioavailability either by physically isolating the sediment from the overlying water or binding metal(loid)s with physical and/or chemical interactions, respectively (Koschorreck et al., 2007; Mohan et al., 2000; Palermo et al., 1998; Zhang et al., 2016). The modelling of metal(loid), methyl mercury, and cyanide release from active capping has demonstrated that the method is effective for at least 100 years (Viana et al., 2008). Active capping materials have several advantages over inert caps: a thinner layer is typically required, and thus, less disturbance is caused to benthic fauna; adsorbents can be introduced as a permeable granule bed, which does not form a hydraulic barrier for water flow; and the costs can be lower compared to dredging (Ghosh et al., 2011; Jacobs and Förstner, 2001; Zhang et al., 2016). However, passive capping is a more mature technology (Azcue et al., 1998), whereas, only a few pilot-scale experiments have been reported in the scientific literature with active capping (Knox et al., 2012). Nevertheless, a commercially available application method for active capping materials has been developed, called reactive core mat, in which an adsorbent is placed between permeable geotextiles (Meric et al., 2013).

Active capping materials for metal(loid) stabilization include commercial ion exchange resins, zeolites, activated carbons (with or without chemical modification), activated alumina, apatite, barite, bentonite, chitosan, red mud, organoclay, titanosilicate, and thiol-modified mesoporous support (Knox et al., 2012; Kwon et al., 2010). Several of these materials are still in the early research stage, have only modest efficiency, or represent too high costs for widespread use. One 
novel option could be geopolymers (or alkali-activated materials), which are mesoporous amorphous aluminosilicates with ion-exchange properties. They have been recently studied for a number of potential environmental applications as adsorbents/ion exchangers (Luukkonen et al., 2016; Luukkonen et al., 2017b; Runtti et al., 2016; Alzboon et al., 2011; Al-Harahsheh et al., 2015), photocatalysts (Gasca-Tirado et al., 2012; Li et al., 2016; Zhang and Liu, 2013), pH buffers (Novais et al., 2016; Novais et al., 2017), membrane and filter materials (Ge et al., 2015; Xu et al., 2015), and for stabilization of hazardous wastes (Asavapisit and Chotklang, 2004). Furthermore, geopolymers can be prepared from several industrial by-products with a simple, up-scalable, and low-energy process.

In this study, sediment samples were collected from two lakes. Both lakes are affected by mine waters and contain a significant amount of anthropogenic-origin metal(loid)s in their sediments, and thus, the motivation for this work was to evaluate a potentially cost-effective remediation method for mine water-impacted sediments. A laboratory-scale in situ treatment was conducted using three adsorbent amendments: alkali-activated blast-furnace-slag, metakaolin geopolymer, and vermiculite. Geopolymers (or alkali-activated materials) were selected as they have not been studied for in situ sediment remediation but they have indicated potential as adsorbents. Metakaolin and blast furnace slag represent low and high-calcium raw materials, respectively, and thus their reaction products are different. Metakaolin forms three-dimensional and highly interconnected aluminosilicate framework (sodium-aluminum-silicate hydrate gel or $\mathrm{N}-\mathrm{A}-\mathrm{S}-\mathrm{H}$ in the cement chemist notation), whereas blast-furnace slag forms structures resembling tobermorite, $\mathrm{Ca}_{5} \mathrm{Si}_{6} \mathrm{O}_{16}(\mathrm{OH})_{2} \cdot \mathrm{nH}_{2} \mathrm{O}$ (calcium-aluminum-silicate-hydrate gel or C-A-S-H). Vermiculite, however, has already been proved to be a potential in situ sediment remediation material with Pseudomonas putida biofilm (Ferronato et al., 2016) and to be effective in decreasing metal bioavailability from soils to plants (Malandrino et al., 2011). Thus, it was selected as a reference. The effect of amendment additions were evaluated by a sequential leaching test, indicating the bioavailability of metal(loid)s, and compared to a blank sample (sediment without adsorbent amendment). 


\section{Materials and methods}

\subsection{Employed adsorbents}

The preparation of geopolymers was based on previous optimization experiments (Luukkonen et al., 2017a) and it is briefly summarized below.

Alkali-activated blast furnace slag (BFS-GP) was prepared by alkali activation of ground-granulated blast-furnace slag (obtained from Finnsementti, Finland; $\mathrm{d}_{50}$ value $10.8 \mu \mathrm{m}$ ). The alkali activator consisted of $8 \mathrm{M} \mathrm{NaOH}$ (analytical grade, VWR Chemicals) and sodium silicate solution (technical grade, VWR Chemicals, molar ratio $\mathrm{SiO}_{2} / \mathrm{Na}_{2} \mathrm{O} \approx 3.5$ ) mixed in a weight ratio of 1.2. The solution was allowed to stand overnight before use. The alkali activator was mixed with the blast-furnace slag in a weight ratio of 0.77 for 15 min using a top-mounted mixer.. The paste was allowed to cure in a plastic bag (at $100 \%$ relative humidity) and room temperature $\left(22^{\circ} \mathrm{C}\right)$ for three days. The obtained monolith was crushed and sieved to particle sizes of 1-4 $\mathrm{mm}$ before use. BFS-GP had the following theoretical molar composition (assuming complete reaction): $\mathrm{SiO}_{2} / \mathrm{Al}_{2} \mathrm{O}_{3}=13.03$, $\mathrm{Na}_{2} \mathrm{O} / \mathrm{SiO}_{2}=0.27, \mathrm{Na}_{2} \mathrm{O} / \mathrm{Al}_{2} \mathrm{O}_{3}=3.57$, and $\mathrm{CaO} / \mathrm{SiO}_{2}=0.56$. Water/solid weight ratio was 0.44 .

The metakaolin geopolymer (MK-GP) was prepared of metakaolin (obtained from Aquaminerals Finland Ltd, Finland) and the alkali activator, which was a mixture of $12 \mathrm{M} \mathrm{NaOH}$ and sodium silicate solution $\left(\mathrm{SiO}_{2} / \mathrm{Na}_{2} \mathrm{O} \approx 3.5\right)$. Metakaolin and alkali activator were mixed in a weight ratio of 1.2. The solution was allowed to stand overnight before use. Alkali activator and metakaolin were mixed in a weight ratio of 1.0 for 15 min using a top-mounted mixer. The paste was allowed to cure for three days in a plastic bag (at 100\% relative humidity) and was crushed and sieved to particle sizes of 1-4 mm. MK-GP had the following theoretical molar composition: $\mathrm{SiO}_{2} / \mathrm{Al}_{2} \mathrm{O}_{3}=2.86$, $\mathrm{Na}_{2} \mathrm{O} / \mathrm{SiO}_{2}=0.28$, and $\mathrm{Na}_{2} \mathrm{O} / \mathrm{Al}_{2} \mathrm{O}_{3}=0.79$. Water to solid weight ratio was 0.48 .

Vermiculite (VER) was obtained from the Palabora mining company (South Africa). It was exfoliated at $450^{\circ} \mathrm{C}$ for $1 \mathrm{~h}$ before use. The particle size distribution was $d_{97}=687 \mu \mathrm{m}, d_{50}=402$ $\mu \mathrm{m}$, and $\mathrm{d}_{10}=255 \mu \mathrm{m}$ (determined using Hosokawa alpine Air Jet Sieve e200 LS). 


\subsection{Adsorbent characterization methods}

The mineralogical composition of adsorbents was determined with powder X-ray diffraction (XRD) using a PanAnalytical Xpert Pro diffractometer (Co Ka radiations generated at $40 \mathrm{kV}$ and $40 \mathrm{~mA}$ ). Patterns were collected from $5^{\circ}$ to $80^{\circ} 2 \theta$ using a scan time of $1.25 \mathrm{~s}$ per $0.02^{\circ} 2 \theta$. Samples were prepared by dispensing a finely ground specimen with ethanol onto a glass plate and allowing the ethanol to vaporize before measurement. Diffractograms were interpreted using the Highscore software (version 3.0) and Chrystallography Open Database 2013 version.

The elemental composition of adsorbents was determined by dissolving samples in a mixture of nitric and hydrochloric acids, according to the EPA 3051 method (EPA, 2007), and then analyzing the solution using an optical emission spectrometer (Thermo Electron IRIS Intrepid II XDL Duo), according to the SFS-EN ISO 11885 standard (Finnish Standard Association, 2009). Silicon concentration was determined using X-ray fluorescence (XRF) spectrometer (PanAnalytical Minipal 4).

\subsection{Sediment and water samples}

Sediment samples were collected from Lake Pyhäjärvi $\left(\mathrm{N} 63,7102^{\circ}, \mathrm{E} 25,9844^{\circ}\right.$, mean depth 8.9 m) and Lake Kivijärvi (N63, 9199, E27, 9306, mean depth 6.6 m) using a Limnos sampler. Locations of these two lakes and places where samples were collected is shown in Figure 1. Sediment samples had total solids of $5.6 \mathrm{~g} / \mathrm{L}$ (Kivijärvi) and $14.6 \mathrm{~g} / \mathrm{L}$ (Pyhäjärvi). Samples were stored in a glass bottle at $+5^{\circ} \mathrm{C}$ in the dark until experiments to minimize chemical changes. Water samples were also collected from the same locations at the upper part of the hypolimnion (mixolimnion in the case of Lake Kivijärvi, which is currently permanently stratified), that is, approximately $4 \mathrm{~m}$ at Kivijärvi and $3 \mathrm{~m}$ at Pyhäjärvi. Water and sediment samples were characterized according to the EPA $3051 \mathrm{~A}$ method (microvawe-assisted $\mathrm{HNO}_{3}$ leach with ICPOES/MS determination) (EPA, 2007) and the SFS-EN ISO 11885 standard (Finnish Standard 


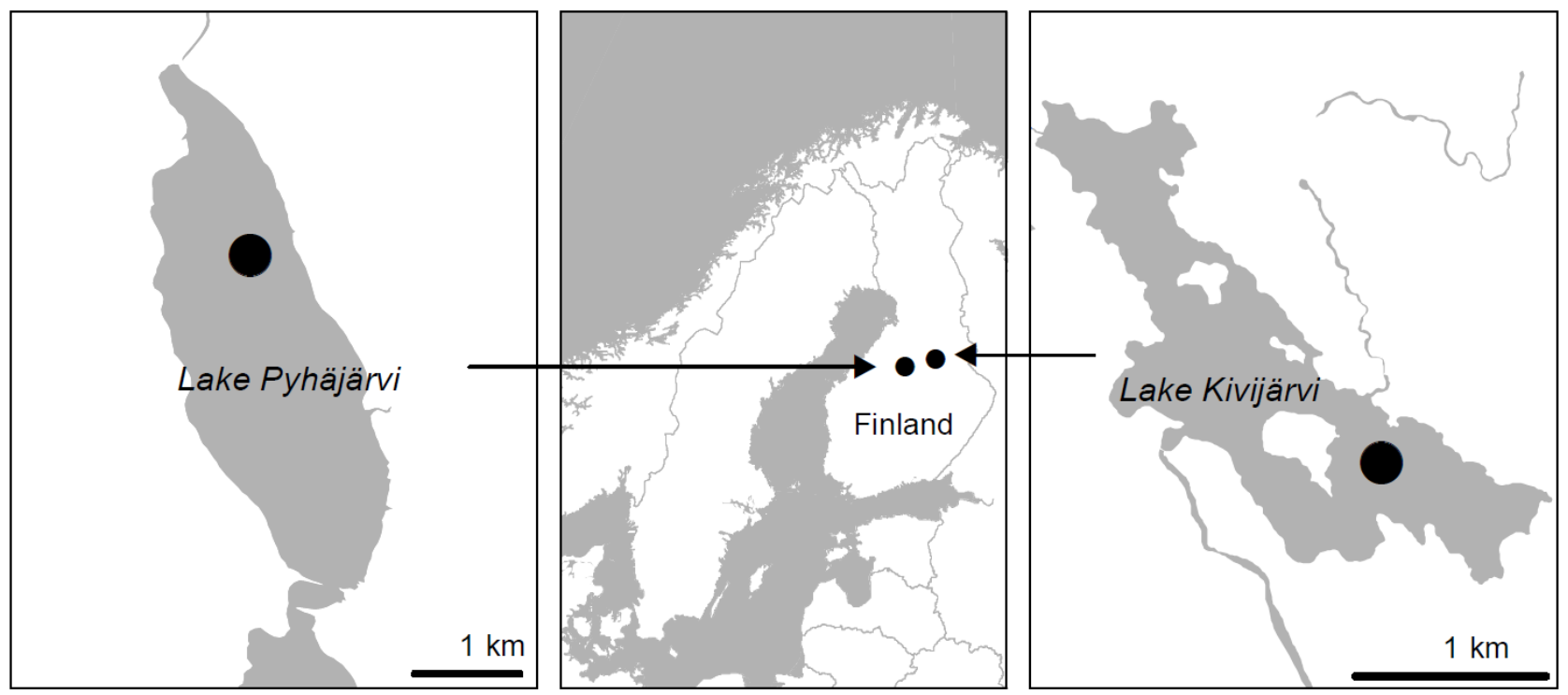

Figure 1. Locations of Lake Kivijärvi and Lake Pyhäjärvi.

\subsection{Stabilization experiments and sequential leaching}

Laboratory-scale in-situ metal stabilization experiments were performed by dosing adsorbents to sediments $(2.2 \%, 4.4 \%$, or $8.7 \%$ as weight of adsorbent per volume of sediment), mixed, kept at $+4^{\circ} \mathrm{C}$ in the dark undisturbed for two weeks. Thereafter, the samples, were evaporated at $105^{\circ} \mathrm{C}$. To evaluate the success of stabilization, a three-step sequential leaching test (Rauret et al., 1999) was applied to the adsorbent-treated sediment samples and blank (untreated) sample. The procedure is shown in Figure 2. In the first step, $0.5 \mathrm{~g}$ of the dried sediment was added to a $50 \mathrm{ml}$ centrifuge tube followed by the addition of $20 \mathrm{~mL}$ of $0.11 \mathrm{M}$ acetic acid and shaking overnight with a mechanical end-over-end shaker. The supernatant (S1) was separated by centrifugation (20 min) 
and analyzed using an optical emission spectrometer (Thermo Electron IRIS Intrepid II XDL Duo), according to the SFS-EN ISO 11885 standard (Finnish Standard Association, 2009). The solid residue was washed with $10 \mathrm{~mL}$ of distilled water, shaken for $15 \mathrm{~min}$, and separated by centrifuging $(20 \mathrm{~min})$. In the second step, $20 \mathrm{~mL}$ of freshly prepared $0.5 \mathrm{M}$ hydroxylammonium chloride solution was added to the solid residue from the first step, and the mixture was shaken overnight. After shaking, the solid residue was separated by centrifugation ( $20 \mathrm{~min}$ ), and the supernatant (S2) was again analyzed. The solid residue was washed with $10 \mathrm{~mL}$ of distilled water (15 min shaking) and centrifuged (20 min). In the third step, $5 \mathrm{~mL}$ of $8.8 \mathrm{M}(30 \%$, w/w) hydrogen peroxide was added to the solid residue from the second step in small amounts. Vessels were covered softly and allowed to react at room temperature for $1 \mathrm{~h}$ with occasional shaking. The leaching was continued at $85^{\circ} \mathrm{C}$ (in a water bath) for $1 \mathrm{~h}$, and then, the solution was evaporated to $1.5 \mathrm{~mL}$ volume. Another $5 \mathrm{~mL}$ of $8.8 \mathrm{M}$ hydrogen peroxide was added, and the volume was allowed to evaporate to $0.5 \mathrm{~mL}$. After cooling to room temperature, $25 \mathrm{~mL}$ of $1 \mathrm{M}$ ammonium acetate solution was added, and mixtures were shaken overnight. The supernatant (S3) was separated by centrifugation (20 $\mathrm{min}$ ), and the solids were washed with $10 \mathrm{~mL}$ of distilled water, shaken for 15 min, and centrifuged (20 min). The final solids (S4) were dissolved according to the EPA 3051 method (EPA, 2007) and analyzed according to the SFS-EN ISO 11885 standard (Finnish Standard Association, 2009). 


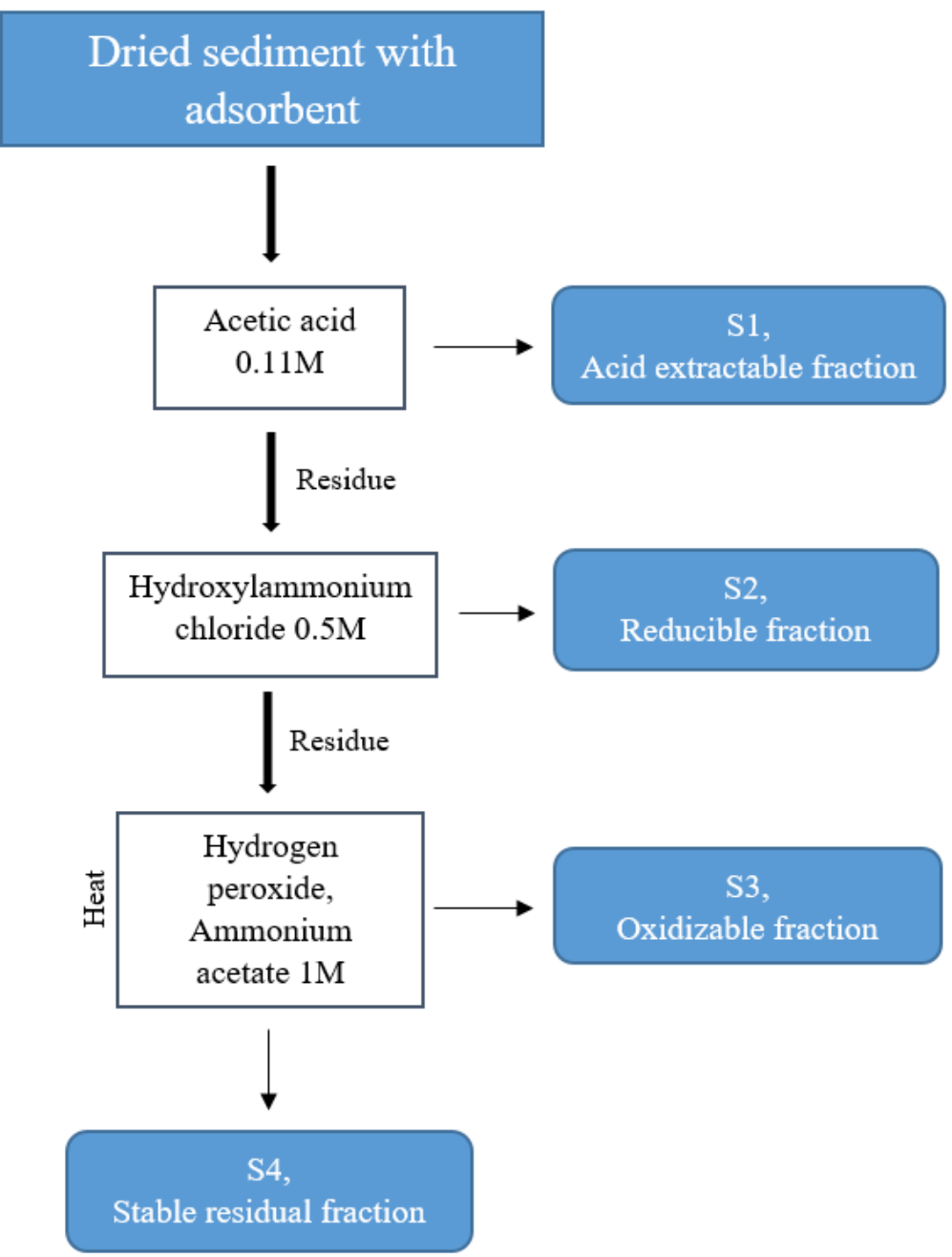

Figure 2. Sequential leaching procedure for the treated contaminated lake sediments.

\section{Results and discussion}

\subsection{Adsorbent characterization}

The elemental compositions of the geopolymer raw materials and vermiculite (Table 1) were determined to evaluate the possible leaching of metal(loid)s out of the adsorbents. The main elements in metakaolin (ideal stoichiometry $\mathrm{Al}_{2} \mathrm{Si}_{2} \mathrm{O}_{7}$ ) are aluminum and silicon with iron, potassium, magnesium, calcium, sulfur, and titanium contained likely in minor impurity phases.

Blast-furnace slag contains mainly calcium, aluminum, silicon, and magnesium, and its structure is usually described as a mixture of poorly crystalline phases such as gehlenite $\left(\mathrm{Ca}_{2} \mathrm{Al}\left[\mathrm{AISiO} \mathrm{O}_{7}\right]\right)$, 
akermanite $\left(\mathrm{Ca}_{2} \mathrm{Mg}\left[\mathrm{Si}_{2} \mathrm{O}_{7}\right]\right)$, and depolymerized glasses (Li et al., 2011). In addition, the amount of sulfur, iron, potassium, sodium, and manganese are relatively high. Vermiculite has an ideal stoichiometry of $\left(\mathrm{Mg}^{+2}, \mathrm{Fe}^{+2}, \mathrm{Fe}^{+3}\right)_{3}\left[(\mathrm{Al}, \mathrm{Si})_{4} \mathrm{O}_{10}\right](\mathrm{OH})_{2} \cdot 4 \mathrm{H}_{2} \mathrm{O}$, and accordingly, the main elements are magnesium, iron, potassium, aluminum, calcium, and silicon. In addition, there are varying trace amounts of potentially toxic elements in all adsorbents, e.g., barium, beryllium, chromium, nickel, lead, tin, and zinc. The largest amount of potentially toxic elements is encountered in the vermiculite as it can adsorb them from the soils from the location it has been excavated (Sipos et al., 2008). The stability of these potentially hazardous elements in adsorbent materials is a potential obstruction for their use, and this is discussed in the section presenting the results of leaching experiments.

Table 1. Elemental composition of metakaolin, blast-furnace slag, and vermiculite.

\begin{tabular}{llll}
\hline Element & Metakaolin $[\mathrm{mg} / \mathrm{kg}]$ & Blast-furnace slag $[\mathrm{mg} / \mathrm{kg}]$ & Vermiculite $[\mathrm{mg} / \mathrm{kg}]$ \\
\hline $\mathrm{Al}$ & 175000 & 50000 & 48300 \\
$\mathrm{Si}$ & 248200 & 127100 & 167900 \\
$\mathrm{Ca}$ & 360 & 287000 & 9670 \\
$\mathrm{Fe}$ & 12200 & 5250 & 54700 \\
$\mathrm{~K}$ & 17700 & 5790 & 43800 \\
$\mathrm{Mg}$ & 6080 & 48700 & 129000 \\
$\mathrm{~S}$ & 350 & 14400 & 71 \\
$\mathrm{Ti}$ & 230 & 6010 & 4050 \\
$\mathrm{~B}$ & 18 & 67 & 0 \\
$\mathrm{Ba}$ & 100 & 550 & 510 \\
$\mathrm{Be}$ & 10 & 4,6 & 1,4 \\
$\mathrm{Cr}$ & 28 & 46 & 230 \\
$\mathrm{Mn}$ & 130 & 2770 & 400
\end{tabular}




\begin{tabular}{llll}
$\mathrm{Na}$ & 360 & 5000 & 340 \\
$\mathrm{Ni}$ & 28 & 1,2 & 150 \\
$\mathrm{P}$ & 420 & 0 & 1950 \\
$\mathrm{~Pb}$ & 35 & 0 & 3,9 \\
$\mathrm{~V}$ & 8,9 & 410 & 18 \\
$\mathrm{Zn}$ & 59 & 0 & 72 \\
$\mathrm{Sn}$ & 54 & 0 & 0 \\
\hline
\end{tabular}

The XRD analysis results of the adsorbents are shown in Figure 3. The diffractogram of MK-GP indicates that quartz $\left(\mathrm{SiO}_{2}\right)$ and muscovite $\left(\mathrm{KAl}_{2}\left(\mathrm{AlSi}_{3} \mathrm{O}_{10}\right)(\mathrm{F}, \mathrm{OH})_{2}\right)$ are present in addition to an amorphous material (hump between $25-40^{\circ} 2 \theta$ ). The amorphous content of the metakaolin-based geopolymer is described as sodium-aluminum-silicate-hydrate gel (N-A-S-H in the cement chemistry notation), the structure of which has been described schematically by some authors (Barbosa et al., 2000; García-Lodeiro et al., 2010; Rowles et al., 2007). The charge-balancing sodium cations in the N-A-S-H gel can be exchanged to other cations, which gives rise to applications as an adsorbent/ion exchanger (O'Connor et al., 2010). The vermiculite sample contains phlogobite and biotite of which vermiculite is a weathering product (Kogel, 2006). However, no vermiculite itself was identified from the diffractogram. BFS-GP contains only faujasite-type zeolite phase as a well-crystallized phase: other phases are amorphous or poorly crystalline, as indicated by the amorphous halo at approximately $30-402 \theta^{\circ}$. The structure of the alkali-activated blast-furnace slag is described as tobermorite-like calcium-sodium-aluminumsilicate-hydrate gel (C-(N)-A-S-H in cement chemistry notation) (Bernal et al., 2014). Similarly to MK-GP, BFS-GP exhibits a structure that has a net negative charge, which is balanced by cations. It sometimes also contains layered double hydroxides, such as hydrotalcite, as secondary reaction products, which explains the potential for anion exchange (Luukkonen et al., 2016). 

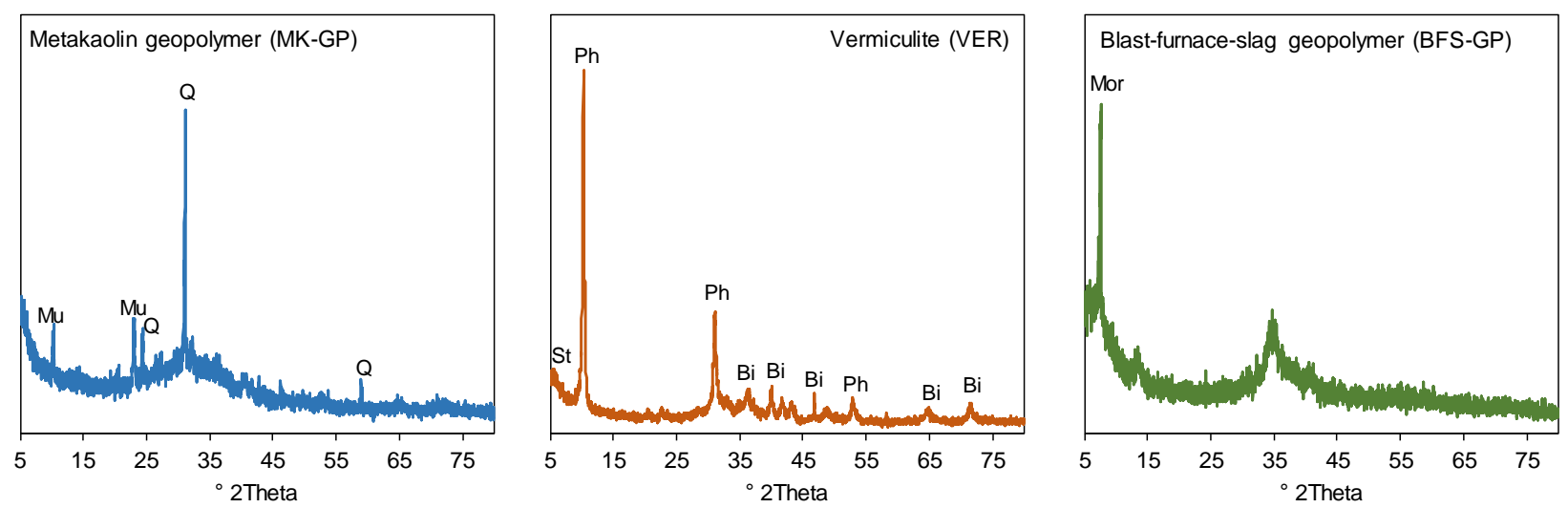

Figure 3. The diffractograms of adsorbents: $\mathrm{Mu}=$ muscovite $\left(\mathrm{KAl}_{2}\left(\mathrm{AlSi}_{3} \mathrm{O}_{10}\right)(\mathrm{F}, \mathrm{OH})_{2}\right), \mathrm{Q}=$ quartz $\left(\mathrm{SiO}_{2}\right), \mathrm{St}=$ stilbite $\left(\mathrm{NaCa}_{4}\left(\mathrm{Si}_{27} \mathrm{Al}_{9}\right) \mathrm{O}_{72} \cdot 28\left(\mathrm{H}_{2} \mathrm{O}\right), \mathrm{Ph}=\right.$ phlogobite $\left(\mathrm{KMg}_{3}\left(\mathrm{AlSi}_{3} \mathrm{O}_{10}\right)(\mathrm{F}, \mathrm{OH})_{2}\right), \mathrm{Bi}=$ biotite $\left(\mathrm{K}(\mathrm{Mg}, \mathrm{Fe})_{3}\left(\mathrm{AlSi}_{3} \mathrm{O}_{10}\right)(\mathrm{F}, \mathrm{OH})_{2}\right)$, and $\mathrm{Fau}=$ faujasite $\left(\left(\mathrm{Na}_{2}, \mathrm{Ca}, \mathrm{Mg}\right)_{3.5}\left[\mathrm{Al}_{7} \mathrm{Si}_{17} \mathrm{O}_{48}\right] \cdot 32\left(\mathrm{H}_{2} \mathrm{O}\right)\right)$.

\subsection{Metal(loid) contamination in the studied lakes}

Lake Pyhäjärvi has been exposed to loading from the Pyhäsalmi mine since 1962. In 2006, the thickness of the contaminated sediments varied between 15 and $20 \mathrm{~cm}$ within the accumulation zone (Mäkinen and Lerssi, 2007). The most notable mining-related increases in metal concentrations are found for $\mathrm{Cu}, \mathrm{Zn}$, and S (146 mg/kg, $481 \mathrm{mg} / \mathrm{kg}$, and 0.6\%, respectively). These concentrations are approximately five times higher than the background.

Lake Kivijärvi is located SE from the Talvivaara mine of Terrafame Ltd. and has received mine water loading since 2009. Especially gypsum pond accident in 2012 caused significant loading of metals from the mine site (Kauppi et al. 2013). The thickness of the contaminated sediment layer was 1-2 cm in Lake Kivijärvi in 2015-2016 (Leppänen et al., 2017). Contamination is most evident in the concentrations of $\mathrm{Ni}, \mathrm{Zn}$, and S (638 mg/kg, $682 \mathrm{mg} / \mathrm{kg}$, and $3.8 \%$ ), which are several times higher than the local background concentrations. High concentrations of $\mathrm{Fe}, \mathrm{Mn}$, and $\mathrm{Na}$ at the sediment surface are also typical for Lake Kivijärvi as a consequence of using $\mathrm{NaOH}$ to increase $\mathrm{pH}$ in the process. In addition, high concentrations of $\mathrm{Ca}$ are found in both Lake Pyhäjärvi and Lake Kivijärvi sediments owing to the liming of the effluent waters. The drainage basin of Lake 
Kivijärvi consists partly of black shale rocks and therefore also natural background values of metals are relatively high (Loukola-Ruskeeniemi et al. 1998).

The average concentrations for the contaminated sediment sections in Lake Pyhäjärvi and Lake Kivijärvi sediments are shown in Table 2. The 0-20 cm sediment sample from Lake Pyhäjärvi (Junttiselkä basin) corresponds well to the contaminated sediment section, while the $0-2 \mathrm{~cm}$ section from Lake Kivijärvi may contain some pre-contamination material. The water quality of the hypolimnia of these lakes in 2016 is presented in Table 3.

Based on these results, the following metal(loid)s were selected to be tested in stabilization experiments: for Lake Kivijärvi sediments - Al, Fe, Ti, Cr, Cu, Zn, Ni, As, Sr, Cd, Ba, and U; and for Lake Pyhäjärvi sediments - Al, Zn, Cu and Cr.

Table 2. Average concentrations for the contaminated sediment sections.

\begin{tabular}{cccc}
\hline & & Lake Kivijärvi & Lake Pyhäjärvi \\
\hline $\mathrm{As}$ & $\mathrm{mg} / \mathrm{kg}$ & 5 & 13 \\
$\mathrm{Cd}$ & $\mathrm{mg} / \mathrm{kg}$ & 2 & 0 \\
$\mathrm{Co}$ & $\mathrm{mg} / \mathrm{kg}$ & 21 & 18 \\
$\mathrm{Cr}$ & $\mathrm{mg} / \mathrm{kg}$ & 17 & 60 \\
$\mathrm{Cu}$ & $\mathrm{mg} / \mathrm{kg}$ & 41 & 146 \\
$\mathrm{Mo}$ & $\mathrm{mg} / \mathrm{kg}$ & 2 & 1 \\
$\mathrm{Ni}$ & $\mathrm{mg} / \mathrm{kg}$ & 638 & 26 \\
$\mathrm{~Pb}$ & $\mathrm{mg} / \mathrm{kg}$ & 28 & 30 \\
$\mathrm{Th}$ & $\mathrm{mg} / \mathrm{kg}$ & 3 & 8 \\
$\mathrm{U}$ & $\mathrm{mg} / \mathrm{kg}$ & 10 & 3 \\
$\mathrm{~V}$ & $\mathrm{mg} / \mathrm{kg}$ & 51 & 70 \\
$\mathrm{Zn}$ & $\mathrm{mg} / \mathrm{kg}$ & 682 & 481
\end{tabular}




\begin{tabular}{cccc}
$\mathrm{Al}$ & $\mathrm{mg} / \mathrm{kg}$ & 11050 & 29361 \\
$\mathrm{Ba}$ & $\mathrm{mg} / \mathrm{kg}$ & 195 & 145 \\
$\mathrm{Ca}$ & $\mathrm{mg} / \mathrm{kg}$ & 10150 & 11412 \\
$\mathrm{Fe}$ & $\mathrm{mg} / \mathrm{kg}$ & 81800 & 51239 \\
$\mathrm{~K}$ & $\mathrm{mg} / \mathrm{kg}$ & 834 & 5221 \\
$\mathrm{Mg}$ & $\mathrm{mg} / \mathrm{kg}$ & 5615 & 8067 \\
$\mathrm{Mn}$ & $\mathrm{mg} / \mathrm{kg}$ & 2855 & 444 \\
$\mathrm{Na}$ & $\mathrm{mg} / \mathrm{kg}$ & 17500 & 454 \\
$\mathrm{P}$ & $\mathrm{mg} / \mathrm{kg}$ & 2525 & 1641 \\
$\mathrm{~S}$ & $\mathrm{mg} / \mathrm{kg}$ & 37850 & 6127 \\
$\mathrm{Ti}$ & $\mathrm{mg} / \mathrm{kg}$ & 386 & 1096 \\
$\mathrm{C}$ & $\%$ & 19 & 7 \\
$\mathrm{~N}$ & $\%$ & 2 & 1 \\
\hline
\end{tabular}

Table 3. Water quality of the hypolimnia of Lake Kivijärvi and Lake Pyhäjärvi (Junttiselkä basin) in the late winter 2016.

\begin{tabular}{cccc}
\hline & & Lake Kivijärvi & Lake Pyhäjärvi \\
\hline $\mathrm{Al}$ & $\mu \mathrm{g} / \mathrm{l}$ & 285 & 210 \\
$\mathrm{As}$ & $\mu \mathrm{g} / \mathrm{l}$ & 0.29 & 3.29 \\
$\mathrm{~B}$ & $\mu \mathrm{g} / \mathrm{l}$ & 14.3 & $<10$ \\
$\mathrm{Ba}$ & $\mu \mathrm{g} / \mathrm{l}$ & 33.7 & 28.9 \\
$\mathrm{Be}$ & $\mu \mathrm{g} / \mathrm{l}$ & $<0.5$ & $<0.5$ \\
$\mathrm{Bi}$ & $\mu \mathrm{g} / \mathrm{l}$ & $<5$ & $<5$ \\
$\mathrm{Cd}$ & $\mu \mathrm{g} / \mathrm{l}$ & $<0.2$ & 0.24 \\
$\mathrm{Co}$ & $\mu \mathrm{g} / \mathrm{l}$ & 3.79 & 4.13 \\
$\mathrm{Cr}$ & $\mu \mathrm{g} / \mathrm{l}$ & 1.02 & $<1$
\end{tabular}




\begin{tabular}{|c|c|c|c|}
\hline $\mathrm{Cu}$ & $\mu \mathrm{g} / \mathrm{l}$ & $<5$ & $<5$ \\
\hline $\mathrm{Li}$ & $\mu \mathrm{g} / \mathrm{l}$ & 141 & 8.71 \\
\hline $\mathrm{Mn}$ & $\mu \mathrm{g} / \mathrm{l}$ & 41400 & 1680 \\
\hline Mo & $\mu \mathrm{g} / \mathrm{l}$ & $<0.2$ & $<0.2$ \\
\hline $\mathrm{Ni}$ & $\mu \mathrm{g} / \mathrm{l}$ & $<5$ & $<5$ \\
\hline $\mathrm{P}$ & $\mu \mathrm{g} / \mathrm{l}$ & 401 & 340 \\
\hline $\mathrm{Pb}$ & $\mu \mathrm{g} / \mathrm{l}$ & $<1$ & $<1$ \\
\hline $\mathrm{Rb}$ & $\mu \mathrm{g} / \mathrm{l}$ & 23.3 & 4.29 \\
\hline $\mathrm{Sb}$ & $\mu \mathrm{g} / \mathrm{l}$ & $<10$ & $<10$ \\
\hline $\mathrm{Se}$ & $\mu \mathrm{g} / \mathrm{l}$ & $<0.5$ & $<0.5$ \\
\hline $\mathrm{Sr}$ & $\mu \mathrm{g} / \mathrm{l}$ & 294 & 127 \\
\hline Th & $\mu \mathrm{g} / \mathrm{l}$ & $<10$ & $<10$ \\
\hline $\mathrm{TI}$ & $\mu \mathrm{g} / \mathrm{l}$ & $<0.2$ & $<0.2$ \\
\hline $\mathrm{U}$ & $\mu \mathrm{g} / \mathrm{l}$ & 1.84 & 0.17 \\
\hline $\mathrm{V}$ & $\mu \mathrm{g} / \mathrm{l}$ & 4.24 & 3.67 \\
\hline $\mathrm{Zn}$ & $\mu \mathrm{g} / \mathrm{l}$ & $<5$ & 40.6 \\
\hline $\mathrm{Ca}$ & $\mathrm{mg} / \mathrm{l}$ & 204 & 106 \\
\hline $\mathrm{Fe}$ & $\mathrm{mg} / \mathrm{l}$ & 74 & 35 \\
\hline $\mathrm{K}$ & $\mathrm{mg} / \mathrm{l}$ & 25 & 3 \\
\hline $\mathrm{Mg}$ & $\mathrm{mg} / \mathrm{l}$ & 205 & 6 \\
\hline $\mathrm{Na}$ & $\mathrm{mg} / \mathrm{l}$ & 2660 & 7 \\
\hline$S$ & $\mathrm{mg} / \mathrm{l}$ & 2080 & 75 \\
\hline
\end{tabular}

\subsection{In situ remediation results}

The variation in the sediment $\mathrm{pH}$ as a function of adsorbent dose after two-week contact time is shown in Figure 4. The speciation of several studied metal(loid)s is strongly affected by $\mathrm{pH}$ : many cations precipitate as hydroxides and oxyanions deprotonate as $\mathrm{pH}$ increases over certain 
threshold values. Among the studied amendments, BFS-GP caused the most striking increase in $\mathrm{pH}$ : from the initial $\mathrm{pH}$ of approximately 6 up to 12 . This is because of the residual alkalinity present in the geopolymer structure. From this point of view, the materials differ from each other. MK-GP increased $\mathrm{pH}$ up to two units while vermiculite caused less than one unit increase. However, the results in Figure 4 most likely exaggerated the $\mathrm{pH}$ increase compared to the actual environmental conditions since the sediments were still and isolated during the experiment. In actual conditions of lakes, the overlaying water column would cause some dilution and mixing.

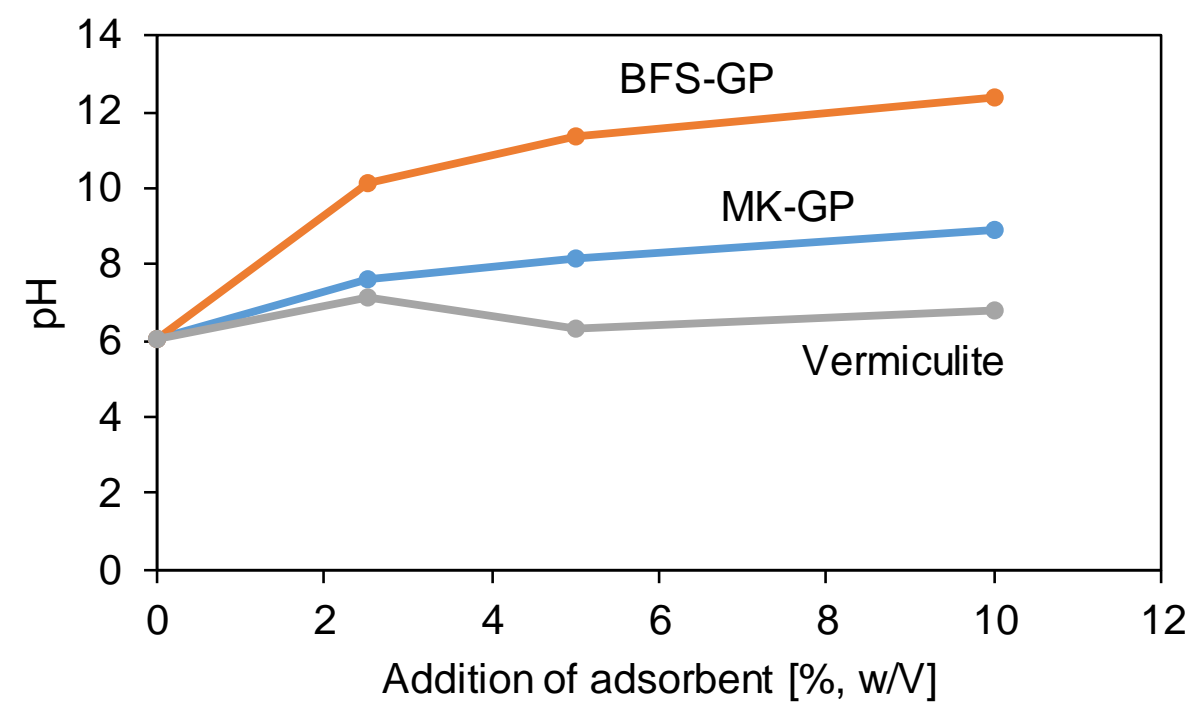

Figure 4. $\mathrm{pH}$ of sediment as a function of adsorbent amendment (in $\%, \mathrm{w} / \mathrm{V}$ ).

The results of the stabilization experiments after two week contact time are shown in Figure 5 as a ratio of $\mathrm{C} / \mathrm{C}_{0}$ for each of the sequential leaching test phases $(\mathrm{S} 1, \mathrm{~S} 2, \mathrm{~S} 3$, or $\mathrm{S} 4) . \mathrm{C}$ and $\mathrm{C}_{0}$ refer to the concentration of the metal(loid) with and without adsorbent amendment, respectively. In the sequential leaching test, $\mathrm{S} 1$ is the acid-extractable fraction, $\mathrm{S} 2$ is the reducible fraction, $\mathrm{S} 3$ is the oxidizable fraction, and S4 is the stable residual fraction. Subsequently, in phases S1 to S3, values $\mathrm{C} / \mathrm{C}_{0}<1$ indicate that the adsorbent amendment has successfully decreased metal(loid) bioavailability and values $\mathrm{C} / \mathrm{C}_{0}>1$ indicate that the adsorbent amendment has increased 
metal(loid) release compared to the blank. In the $\mathrm{S} 4$ phase, the result $\mathrm{C} / \mathrm{C}_{0}>1$ indicates the enhanced accumulation of metal(loid) in the stable fraction compared to the blank sample.
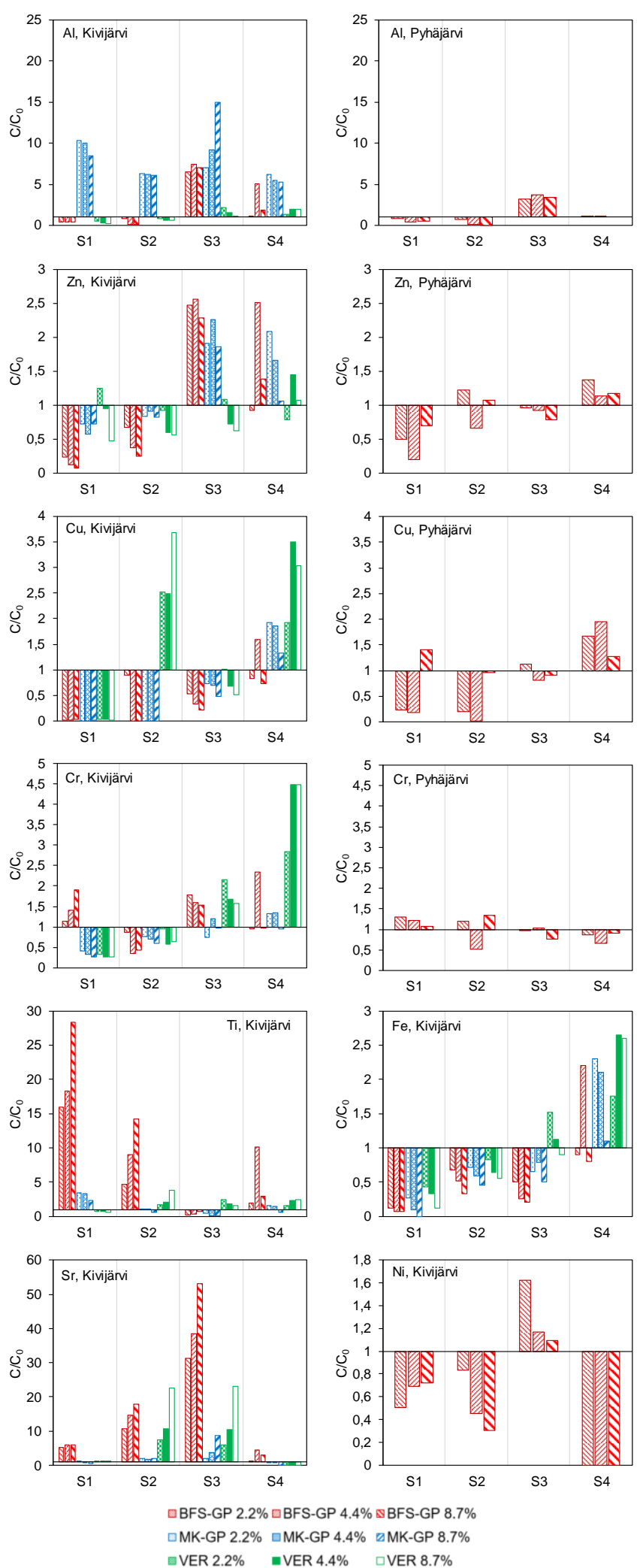
Figure 5. Results of the sequential leaching experiments after two week contact time. $\mathrm{S} 1$ is the acid-extractable fraction, S2 is the reducible fraction, S3 is the oxidizable fraction, and S4 is the residual fraction. $\mathrm{C} / \mathrm{C}_{0}$ is the ratio of the concentration in the specific phase $(\mathrm{S} 1, \mathrm{~S} 2, \mathrm{~S} 3$, or $\mathrm{S} 4)$ to concentration in unamended sediment.

Aqueous soluble aluminum occurs as $\mathrm{Al}^{3+}$. Aluminum is not acutely toxic to humans, but for instance, a link between Alzheimer disease and aluminum intake is suspected (Gupta et al., 2005). The provisional tolerable weekly intake value for aluminum is $0.9 \mathrm{mg} / \mathrm{L}$ (World Health Organization, 2015). However, aluminum is usually sparingly soluble at typical $\mathrm{pH}$ encountered in natural aqueous environments: the precipitation of $\mathrm{Al}(\mathrm{OH})_{3}$ occurs already at $\mathrm{pH}>4$, but at $\mathrm{pH}>11$, soluble $\mathrm{Al}(\mathrm{OH})_{4}^{-}$becomes the predominant species (Schweitzer and Pesterfield, 2010). The results of BFS-GP indicated enhanced binding of aluminum at acid-extraction (S1) and reduction (S2) phases compared to the blank. In the S3 (oxidizable fraction), however, there was a release of aluminum compared to the blank. Finally, in the $S 4$ (residual) fraction, BFS-GP results indicated accumulation of aluminum in the stabile residual fraction. MK-GP, on the hand, released aluminum significantly compared to the blank in the S1-S3 phases, possibly due to partial solubilization of the aluminosilicate structure of MK-GP. With vermiculite, there was a minor stabilizing effect observable in S1 and S2, a slight release of $\mathrm{Al}$ in S3, and, again, a minor accumulation of $\mathrm{Al}$ in the stable S4 fraction. Interestingly, the dose of adsorbent had no clear trend on the aluminum stabilization results, which is likely due to the effect of $\mathrm{pH}$ : all adsorbents increased $\mathrm{pH}$ clearly over the $\mathrm{Al}(\mathrm{OH})_{3}$ precipitation value independent of dose. BFS-GP was tested with both lake sediments, and it performed similarly.

Zinc is present in the aqueous environment as soluble $\mathrm{Zn}^{2+}$ at $\mathrm{pH}<6.5$, precipitated $\mathrm{Zn}(\mathrm{OH})_{2}$ at $\mathrm{pH}$ 6.5-12.5, and then again soluble $\mathrm{Zn}(\mathrm{OH})_{4}{ }^{2-}$ at $\mathrm{pH}>13$ (Schweitzer and Pesterfield, 2010). There are no health-based guideline values for zinc in drinking water, although concentrations above 3 mg/L cause unpleasant color and taste (World Health Organization, 1996). In the Lake Kivijärvi samples, all adsorbents decreased zinc availability compared to the blank with certain dosing 
amounts in the acid-extraction (S1) and reduction (S2) stages. During the oxidative leaching (S3), however, BFS-GP and MK-GP released zinc while vermiculite was still able to keep zinc bounded. In fact, vermiculite (without exfoliation) has previously indicated promising adsorption efficiency towards zinc at pH > 7 (Abollino et al., 2008). Strikingly different results were obtained for Lake Pyhäjärvi, where BFS-GP was also able to bind Zn at oxidative conditions (S3). These results suggest that other water chemistry parameters (such as the presence of ligands) might affect the efficiency of the adsorbent amendments. Results of the stable fraction (S4) indicate that all adsorbents have accumulated zinc compared to the blank. Results of Lake Pyhäjärvi indicate also that $4.4 \%$ is the optimum dose for BFS-GP treatment of this sediment (decreased dissolution of $\mathrm{Zn}$ in S1-S3 and increased accumulation in S4).

Copper has the most stable oxidation state at +2 and thus occurs as soluble $\mathrm{Cu}^{2+}$ when $\mathrm{pH}$ is below approximately 5 (Schweitzer and Pesterfield, 2010). The WHO has a guideline value of 2 mg/L for copper in drinking water (World Health Organization, 2015). BFS-GP and MK-GP can reduce copper availability effectively in S1, S2, and S3 leaching stages, while vermiculite releases copper in reducing conditions (S2). Vermiculite has been shown to be effective for copper adsorption at pH > 7 (Abollino et al., 2008; Vijayaraghavan and Raja, 2015). All adsorbents have accumulated copper to the stable fraction, which can be seen from the results of phase S4. However, the lowest and highest BFS-GP doses have resulted in a decreased accumulation of copper to the stable phase (S4). The results of the samples from Pyhäjärvi show that a BFS-GP dose of $4.4 \%$ results in decreased dissolution in phases S1-S3 and increased accumulation to stabile phase (S4), while with other doses, there is inconsistency. For a Chironomus genus specimen (a robust widespread genus of nonbiting midges that can be found around the world also in harsh and oxygen lacking conditions like in stratificated lakes) detrimental effects can be seen in concentrations of $89.2 \mathrm{mg} / \mathrm{kg}$ meaning that utilizing geopolymers could have an effect on the survival possibilities of the benthos in Lake Pyhäjärvi (Roman et.al., 2007).

Aqueous chromium is most commonly present at oxidations states +3 or +6 , that is, as cationic $\mathrm{Cr}^{3+}$ or as chromate oxyanions (for instance, $\mathrm{CrO}_{4}{ }^{2-}$ ), respectively (Schweitzer and Pesterfield, 
2010). Trivalent chromium is the predominant form in natural waters, while the significantly toxic hexavalent chromium originates usually from industrial loading. WHO has a provisional guideline value of $0.05 \mathrm{mg} / \mathrm{L}$ (total chromium) for drinking water (World Health Organization, 1996). $\mathrm{Cr}(\mathrm{III})$ precipitates as $\mathrm{Cr}_{2} \mathrm{O}_{3}$ or $\mathrm{Cr}(\mathrm{OH})_{3}$ when $\mathrm{pH}$ is above approximately 4, while $\mathrm{Cr}(\mathrm{VI})$ stays soluble and deprotonates as $\mathrm{pH}$ increases (Schweitzer and Pesterfield, 2010). The speciation of chromium was not performed for the collected samples, and thus, the results are interpreted as total chromium. Only BFS-GP was able to decrease chromium solubility in the acid-extraction (S1) stage. In reducing conditions (S2), however, all adsorbents released chromium compared to the blank. In oxidative conditions (S3), BFS-GP and vermiculite were able to decrease availability. Finally, the accumulation of chromium to stable fraction (S4) was noticed with all adsorbents although there was some inconsistency in the results. It should be noted that MK-GP and vermiculite can adsorb only cations, whereas BFS-GP also has anion exchange properties as demonstrated previously (Luukkonen et al., 2016).

Dissolved titanium is typically present in aqueous environments at the oxidation state +4 , for instance, as non-ionic $\mathrm{Ti}(\mathrm{OH})_{4}$. However, it is more frequently present in the insoluble form (e.g., $\mathrm{TiO}_{2}$ ), and as such, it is highly stable and poses no environmental or health risks (Schweitzer and Pesterfield, 2010). According to results in Figure 5, BFS-GP releases titanium in the acid-extraction (S1) and reduction (S2) stages but reduced titanium release in the oxidative extraction phase (S3) compared to the blank. As can be seen from Table 1 , there is approximately $0.6 \% \mathrm{Ti}$ in the blastfurnace slag. MK-GP also releases minor amount of $\mathrm{Ti}$ in the $\mathrm{S} 1$ and $\mathrm{S} 2$ extraction stages and stabilizes Ti compared to the blank in the S3 phase. Vermiculite has $\mathrm{C} / \mathrm{C}_{0}$ of approximately 1 in the S1 extraction stage (i.e., no effect), but significant release of Ti takes place in S2 and S3. In the S4 (residual) fraction, MK-GP and vermiculite indicate higher Ti content compared to the blank.

Iron is an essential nutritional element, which can be present at +2 or +3 oxidation stages. When reducing conditions prevail, $\mathrm{Fe}^{2+}$ stays soluble up to $\mathrm{pH}$ approximately 6 (Schweitzer and Pesterfield, 2010). However, $\mathrm{Fe}^{2+}$ is easily oxidized to $\mathrm{Fe}^{3+}$, which precipitates as hydroxides at $\mathrm{pH}$ of approximately 3 (Schweitzer and Pesterfield, 2010). BFS-GP and MK-GP bind iron effectively at 
stages $\mathrm{S} 1$ to $\mathrm{S} 3$, and enhanced accumulation to sediment dry matter is observed for all adsorbents.

Strontium occurs as soluble $\mathrm{Sr}^{2+}$ up to $\mathrm{pH}$ of approximately 14 and then precipitates as $\mathrm{Sr}(\mathrm{OH})_{2}$ (Schweitzer and Pesterfield, 2010). Strontium is not currently regulated in drinking water although concentration above $4 \mathrm{mg} / \mathrm{L}$ can cause detrimental health (O'Donnell et al., 2016). Strontium has synthetic radioactive isotopes, such as ${ }^{90} \mathrm{Sr}$ (half-life 28.9 years), which are associated with certain cancers (Guillén et al., 2010). Stabilization of strontium was not effective with any of the studied adsorbents and, in fact, they released strontium during all extraction stages compared to the blank.

Nickel is present in aqueous environments as soluble $\mathrm{Ni}^{2+}$ at $\mathrm{pH}$ less than 8 , as precipitated hydroxide $\left(\mathrm{Ni}(\mathrm{OH})_{2}\right)$ between $\mathrm{pH} 8-14$, and as soluble $\mathrm{HNiO}_{2}{ }^{-}$at $\mathrm{pH}$ higher than 14 (Schweitzer and Pesterfield, 2010). The guideline value for nickel in drinking water is $70 \mu \mathrm{g} / \mathrm{L}$ (World Health Organization, 2005). The typical symptom from nickel exposure is allergic contact dermatitis. Nickel is also carcinogenic although the risk from oral exposure is unclear (IARC, 1990). Stabilization of nickel was studied with BFS-GP from Lake Kivijärvi sediment, and it was successful in S1 and S2 extraction stages. However, in the S3 stage (oxidative extraction), nickel was less stable with BFS-GP compared to the blank without adsorbent. Finally, in the residue (S4) stage, there was no accumulation of nickel observable compared to the blank. . For one Chironomus genus specimen detrimental effects can be seen in concentrations of $538 \mathrm{mg} / \mathrm{kg}$ meaning that utilizing geopolymers could have an effect on the survival possibilities of the benthos in Lake Kivijärvi (Karsten et. al., 2011).

In addition to the abovementioned metal(loid)s, uranium, cadmium, and arsenic were also analyzed but the concentrations were extremely small $(<<10 \mu \mathrm{g} / \mathrm{L}$ in all extraction stages), and thus, their results are not shown. Regarding barium, all adsorbents exhibited a significant release especially in the acid-extraction stage (S1) but also during the reduction (S2) and oxidation (S3) stages. 
The suitability of adsorbent materials for each of the studied metal(loid)s can be summarized using Table 4.

Table 4. Summary of the metal(loid) stabilization results.

\begin{tabular}{lll}
\hline Metal(loid) & The most suitable adsorbent & Remarks \\
\hline $\mathrm{Al}$ & Vermiculite, BFS-GP & Not effective at oxidative conditions \\
$\mathrm{Zn}$ & Vermiculite, BFS-GP & Inconsistent results with BFS-GP at oxidative \\
& & conditions \\
$\mathrm{Ni}$ & BFS-GP & Not effective at oxidative conditions \\
$\mathrm{Cu}$ & BFS-GP, MK-GP & - \\
$\mathrm{Cr}$ (total) & MK-GP & Dose 2.2\% was the optimum \\
$\mathrm{Fe}$ (total) & BFS-GP, MK-GP & - \\
$\mathrm{Ti}$ & None & None of the studied adsorbents was able to \\
& & withstand all conditions consistently \\
$\mathrm{Sr}$ & None & All adsorbents released strontium \\
$\mathrm{Ba}$ & None & All adsorbents released barium \\
\hline
\end{tabular}

\section{Conclusions}

The suitability of metakaolin geopolymer, alkali-activated blast-furnace-slag, and exfoliated vermiculite were studied for the in situ stabilization (i.e., active gapping) of potentially toxic metal(loid)s in lake sediments. Sediment samples were collected from two Finnish lakes, which have been subjected to metal(loid) loading from human activities. The suitability was evaluated by a sequential leaching test of amendment-containing sediments compared to a blank sample (without amendment). The aim of the study was to observe the technical feasibility of these novel amendments to be used in the remediation of lakes instead of dredging. Studied metal(loid)s were $\mathrm{Al}, \mathrm{Zn}, \mathrm{Ni}, \mathrm{Cu}, \mathrm{Cr}, \mathrm{Ti}, \mathrm{Fe}, \mathrm{Sr}$, and $\mathrm{Ba}$. In addition, $\mathrm{As}, \mathrm{Cd}$, and $\mathrm{U}$ were also studied, but their concentrations were too low to observe the stabilization effect of the adsorbents. 
Following conclusions can be made:

- Blast-furnace-slag geopolymer proved to be the most versatile of the studied adsorbents as it could stabilize Al, Zn, Ni, Cu, and Fe simultaneously. However, it was not always effective at oxidative conditions of the leaching test. One possible reason for the better adsorption capacity is tobermorite, which is shown to have good adsorption properties. In addition, it likely adds Ca to the pore waters of the sediment, reducing metal toxicity.

- Vermiculite could be used for Al and Zn

- Metakaolin geopolymer was effective for stabilizing $\mathrm{Cu}$ and Fe.

- The observed performance was difference between the two studied lakes, which implies that other water chemistry parameters also have an effect on the adsorbent amendment efficiency.

- Thus, the efficiency of active capping needs to be determined case specifically.

As a final word, it can be concluded that the results demonstrated the preliminary suitability of geopolymers as active capping materials of metal(loid)-contaminated lake sediment and possibly in improving the living conditions of benthos in comparison to more invasive remediation methods.

\section{Acknowledgements}

The authors wish to thank all the sources of funding for the project. This study was financially supported by the EU through the KaiHali project, Finnish Cultural foundation by The Central Ostrobothnia Regional Fund, Tauno Tönning Research foundation, and Kerttu Saalasti foundation. The authors wish to acknowledge Dr. Ester Takaluoma for participating in sediment sampling and Seija Liikanen for conducting the ICP-OES analysis.

\section{REFERENCES}


Abollino, O., Giacomino, A., Malandrino, M., and Mentasti E., 2008. Interaction of metal ions with montmorillonite and vermiculite, Applied Clay Science, 38 (3-4), 227-236.

https://doi.org/10.1016/j.clay.2007.04.002

Al-Harahsheh, Mohammad S., et al., 2015. "Fly ash based geopolymer for heavy metal removal: A case study on copper removal." Journal of Environmental Chemical Engineering, 3 (3) 1669-1677. https://doi.org/10.1016/j.jece.2015.06.005

\section{Al-Zboon, K., Al-Harahsheh, M. S., \& Hani, F. B. 2011. Fly ash-based geopolymer for Pb removal} from aqueous solution. Journal of hazardous materials, 188 (1-3), 414-421.

\section{https://doi.org/10.1016/j.jhazmat.2011.01.133}

Asavapisit, S. and Chotklang D., 2004. Solidification of electroplating sludge using alkali-activated pulverized fuel ash as cementitious binder, Cement and Concrete Research, 34 (2), 349-353. https://doi.org/10.1016/j.cemconres.2003.08.012

Azcue, J. M., Zeman, A., and Förstner U., 1998. International review of application of subaqueous capping techniques for remediation of contaminated sediments, Proceedings of the 3rd International Congress for Environmental Geotechnics, Lisbon.

Barbosa, V. F., MacKenzie, K. J., and Thaumaturgo C., 2000. Synthesis and characterisation of materials based on inorganic polymers of alumina and silica: sodium polysialate polymers, International Journal of Inorganic Materials, 2 (4), 309-317. https://doi.org/10.1016/S1466$6049(00) 00041-6$

Bernal, S. A., Provis, J. L., Fernández-Jiménez, A., Krivenko, P. V., Kavalerova, E., Palacios, M., and Shi C., 2014. Binder chemistry-high-calcium alkali-activated materials, in Alkali Activated Materials Anonymous, pp. 59-91, Springer. 
Cagnin, R. C., Quaresma, V. S., Chaillou, G., Franco, T., and Bastos A. C., 2017. Arsenic enrichment in sediment on the eastern continental shelf of Brazil, Science of the Total Environment, 607, 304-316. https://doi.org/10.1016/j.scitotenv.2017.06.162

EPA, 2007. METHOD 3051A MICROWAVE ASSISTED ACID DIGESTION OF SEDIMENTS, SLUDGES, SOILS, AND OILS.

Ferronato, C., Silva, B., Costa, F., and Tavares T., 2016. Vermiculite bio-barriers for Cu and Zn remediation: an eco-friendly approach for freshwater and sediments protection, International Journal of Environmental Science and Technology, 13(5), 1219-1228.

https://doi.org/10.1007/s13762-016-0957-8

Finnish Standard Association, S., 2009. Water quality - Determination of selected elements by inductively coupled plasma optical emission spectrometry (ICP-OES) (ISO 11885:2007).

Finnish Standard Association, 2016, Water quality. Application of inductively coupled plasma mass spectrometry (ICP-MS). Part 2: Determination of selected elements including uranium isotopes (ISO 17294-2:2016)

García-Lodeiro, I., Fernández-Jiménez, A., Palomo, A., and Macphee D. E., 2010. Effect of calcium additions on N-A-S-H cementitious gels, Journal of the American Ceramic Society, 93(7), 1934-1940. doi:10.1111/j.1551-2916.2010.03668.x

Gasca-Tirado, J. R., Manzano-Ramírez, A., Villaseñor-Mora, C., Muñiz-Villarreal, M. S., ZaldivarCadena, A. A., Rubio-Ávalos, J. C., Borrás, V. A., and Mendoza R. N., 2012. Incorporation of photoactive TiO 2 in an aluminosilicate inorganic polymer by ion exchange, Microporous and Mesoporous Materials, 153, 282-287. https://doi.org/10.1016/j.micromeso.2011.11.026

Ge, Y., Yuan, Y., Wang, K., He, Y., and Cui X., 2015. Preparation of geopolymer-based inorganic membrane for removing Ni 2 from wastewater, Journal of Hazardous Materials, 299, 711-718. https://doi.org/10.1016/j.jhazmat.2015.08.006 
Ghosh, U., Luthy, R. G., Cornelissen, G., Werner, D., and Menzie C. A., 2011. In-situ sorbent amendments: a new direction in contaminated sediment management, Environmental Science \& Technology. doi:10.1021/es102694h

González-Fernández, B., Rodríguez-Valdés, E., Boente, C., Menéndez-Casares, E., FernándezBraña, A. and Gallego J. R., 2018. Long-term ongoing impact of arsenic contamination on the environmental compartments of a former mining-metallurgy area., Science of the Total Environment, 610, 820. https://doi.org/10.1016/j.scitotenv.2017.08.135

Guillén, F. J., Baeza, A., and Salas A., 2010. Strontium: Radionuclides, Encyclopedia of Inorganic and Bioinorganic Chemistry.

Gupta, V. B., Anitha, S., Hegde, M. L., Zecca, L., Garruto, R. M., Ravid, R., Shankar, S. K., Stein, R., Shanmugavelu, P., and Rao K. J., 2005. Aluminium in Alzheimer's disease: are we still at a crossroad?, Cellular and Molecular Life Sciences CMLS, 62(2), 143-158.

https://doi.org/10.1007/s00018-004-4317-3

IARC, 1990. IARC Monographs on the Evaluation of Carcinogenic Risks to Humans, Vol. 49. Chromium, Nickel and Welding, IARC Monographs; Vol. 49, 257-445 pp., International Agency for Research on Cancer, Lyon.

Jacobs, P. and Förstner U., 2001. Managing contaminated sediments, Journal of Soils and Sediments, 1(4), 205-212. https://doi.org/10.1007/BF02987726

Jain, M. K. and Das A., 2017. Impact of mine waste leachates on aquatic environment: a review, Current Pollution Reports, 3(1), 31-37. https://doi.org/10.1007/s40726-017-0050-z

Karsten, L., Doig, L., Whitey-Sobey. S., 2011. Toxicity of uranium, molybdeum, nickel and arsenic to Hualella azteca and Chironomus dilutus in water-only and spiked-sediment toxicity tests, Ecotoxicology and Environmental Safety, 74, 1171-1179.

https://doi.org/10.1016/j.ecoenv.2011.02.014 
Kauppi,S., Mannio, J., Hellsten, S., Nystén, T., Jouttijärvi, T., Huttunen, M., Ekholm, P., Tuominen, S., Porvari, P., Karjalainen, A., Sara-Aho, T., Saukkoriipi, J. and Maunula, M., 2013. Suomen ympäristökeskuksen raportteja, ISSN 1796-1726; 11 ISBN 978-952-11-4151-5

Klavinš, M., Briede, A., Rodinov, V., Kokorite, I., Parele, E. and Klavina I., 2000. Heavy metals in rivers of Latvia, Science of the Total Environment, 262(1), 175-183. https://doi.org/10.1016/S00489697(00)00597-0

Knox, A. S., Paller, M. H. and Roberts J., 2012. Active capping technology-New approaches for in situ remediation of contaminated sediments, Remediation Journal, 22(2), 93-117. doi:

10.1002/rem.21313

Kogel, J. E., 2006. Industrial Minerals \& Rocks: Commodities, Markets, and Uses, SME.

Koschorreck, M., Bozau, E., Frömmichen, R., Geller, W., Herzsprung, P. and Wendt-Potthoff K., 2007. Processes at the sediment water interface after addition of organic matter and lime to an acid mine pit lake mesocosm, Environmental Science \& Technology, 41(5), 1608-1614. doi: $10.1021 /$ es0614823

Kwon, S., Thomas, J., Reed, B. E., Levine, L., Magar, V. S., Farrar, D., Bridges, T. S., and Ghosh U., 2010. Evaluation of sorbent amendments for in situ remediation of metal-contaminated sediments, Environmental Toxicology and Chemistry, 29(9), 1883-1892. doi: 10.1002/etc.249

Leppänen, J. J., Weckström, J. and Korhola A., 2017. Multiple mining impacts induce widespread changes in ecosystem dynamics in a boreal lake, Scientific Reports, 7(1), 10581. doi:10.1038/s41598-017-11421-8

Li, C., Sun, H. H. and Li L. T., 2011. Glass phase structure of blast furnace slag, Advanced Materials Research. https://doi.org/10.4028/www.scientific.net/AMR.168-170.3 
Li, C., He, Y., Tang, Q., Wang, K., and Cui X., 2016. Study of the preparation of CdS on the surface of geopolymer spheres and photocatalyst performance, Materials Chemistry and Physics, 178, 204-210. https://doi.org/10.1016/j.matchemphys.2016.05.013

Loukola-Ruskeeniemi K., Uutela, A., Tenhola, M. and Paukola, T., 1998. Environmental impact of metalliferousblack shales at Talvivaara in Finland, with indication of lake acidification 9000 years ago. Journal of Geochemical Exploration 64: 395-407 https://doi.org/10.1016/S03756742(98)00047-8

Luukkonen, T., Runtti, H., Niskanen, M., Tolonen, E., Sarkkinen, M., Kemppainen, K., Rämö, J. and Lassi U., 2016. Simultaneous removal of Ni (II), As (III), and Sb (III) from spiked mine effluent with metakaolin and blast-furnace-slag geopolymers, Journal of Environmental Management, 166, 579-588. https://doi.org/10.1016/j.jenvman.2015.11.007

Luukkonen, T., Tolonen, E., Runtti, H., Kemppainen, K., Permki, P., Rämö, J., and Lassi U., 2017a. Optimization of the metakaolin geopolymer preparation for maximized ammonium adsorption capacity, Journal of Materials Science, 52(16), 9363-9376. https://doi.org/10.1007/s10853-017-1156-9

Luukkonen, T., Věžníková, K., Tolonen, E., Runtti, H., Yliniemi, J., Hu, T., Kemppainen, K. and Lassi U., 2017b. Removal of ammonium from municipal wastewater with powdered and granulated metakaolin geopolymer, Environmental Technology, 1-10, doi: 10.1080/09593330.2017.1301572.

Mäkinen, J. and Lerssi J., 2007. Characteristics and seasonal variation of sediments in Lake Junttiselkä, Pyhäsalmi, Finland, Mine Water and the Environment, 26(4), 217-228. https://doi.org/10.1007/s10230-007-0015-3

Malandrino, M., Abollino, O., Buoso, S., Giacomino, A., La Gioia, C., and Mentasti, E., 2011. Accumulation of heavy metals from contaminated soil to plants and evaluation of soil remediation by vermiculite, Chemosphere, 82(2), 169-178. https://doi.org/10.1016/j.chemosphere.2010.10.028 
Meric, D., Hellweger, F., Barbuto, S., Rahbar, N., Alshawabkeh, A. N., and Sheahan T. C., 2013. Model prediction of long-term reactive core mat efficacy for capping contaminated aquatic sediments, Journal of Environmental Engineering, 139(4), 564-575. doi:10.1061/(ASCE)EE.19437870.0000635

Mohan, R. K., Brown, M. P., and Barnes C. R., 2000. Design criteria and theoretical basis for capping contaminated marine sediments, Applied Ocean Research, 22(2), 85-93. https://doi.org/10.1016/S0141-1187(00)00003-1

Mulligan, C. N., Yong, R. N., and Gibbs B. F., 2001. An evaluation of technologies for the heavy metal remediation of dredged sediments, Journal of Hazardous Materials, 85(1), 145-163, doi: //doi.org/10.1016/S0304-3894(01)00226-6.

Novais, R. M., Buruberri, L. H., Seabra, M. P., Bajare, D. and Labrincha J. A., 2016. Novel porous fly ash-containing geopolymers for pH buffering applications, Journal of Cleaner Production, 124, 395-404. https://doi.org/10.1016/j.jclepro.2016.02.114

Novais, R. M., Seabra, M. P. and Labrincha J. A., 2017. Porous geopolymer spheres as novel pH buffering materials, Journal of Cleaner Production, 143, 1114-1122. https://doi.org/10.1016/j.jclepro.2016.12.008

O'Connor, S. J., MacKenzie, K. J., Smith, M. E., and Hanna J. V., 2010. Ion exchange in the charge-balancing sites of aluminosilicate inorganic polymers, Journal of Materials Chemistry, 20(45), 10234-10240. doi:10.1039/c0jm01254h

O'Donnell, A. J., Lytle, D. A., Harmon, S., Vu, K., Chait, H., and Dionysiou D. D., 2016. Removal of strontium from drinking water by conventional treatment and lime softening in bench-scale studies, Water Research,103, 319-333. https://doi.org/10.1016/j.watres.2016.06.036

Palermo, M., Maynord, S., Miller, J., and Reible D., 1998. Guidance for in-situ subaqueous capping of contaminated sediments, Chicago, Great Lakes National Program Office. 
Rasheed, K. and Balchand A. N., 2007. Environmental studies on impacts of dredging, The International Journal of Environmental Studies, 58(6), 703-725, doi:

10.1080/00207230108711363.

Rauret, G., López-Sánchez, J. F., Sahuquillo, A., Rubio, R., Davidson, C., Ure, A., and Quevauviller P., 1999. Improvement of the BCR three step sequential extraction procedure prior to the certification of new sediment and soil reference materials, Journal of Environmental Monitoring, 1(1), 57-61. doi:10.1039/A807854H

Roman, Y., De Schamphelaere, K., Nguyen, L., Janssen, C., 2007. Chronic toxicity of copper to five benthic invertebrates in laboratory-formulated sediment: Sensitivity comparison and preliminary risk assessment, Science of the Total Environment 387, 128-140. https://doi.org/10.1016/j.scitotenv.2007.06.023

Rowles, M. R., Hanna, J. V., Pike, K. J., Smith, M. E., and O'Connor B. H., 2007. 29 Si, 27 Al, 1 H and 23 Na MAS NMR study of the bonding character in aluminosilicate inorganic polymers, Applied Magnetic Resonance, 32(4), 663. https://doi.org/10.1007/s00723-007-0043-y

Runtti, H., Luukkonen, T., Niskanen, M., Tuomikoski, S., Kangas, T., Tynjälä, P., Tolonen E-T., Sarkkinen, M., Kemppainen, K., Rämö, J., and Lassi U., 2016. Sulphate removal over bariummodified blast-furnace-slag geopolymer, Journal of Hazardous Materials, 317(Supplement C), 373-384, doi: //doi.org/10.1016/j.jhazmat.2016.06.001.

Salomons, W. and Stigliani W. M., 2012. Biogeodynamics of Pollutants in Soils and Sediments: Risk Assessment of Delayed and Non-Linear Responses, Springer Science \& Business Media.

Saup, C. M., Williams, K. H., Rodrguez-Freire, L., Cerrato, J. M., Johnston, M. D., and Wilkins M. J., 2017. Anoxia stimulates microbially catalyzed metal release from Animas River sediments, Environmental Science: Processes \& Impacts, 19(4), 578-585. doi:10.1039/C7EM00036G

Schweitzer, G. K. and Pesterfield L. L., 2010. The Aqueous Chemistry of the Elements, OUP USA. 
Simpson, S. L., Apte, S. C. and Batley G. E., 2000. Effect of short-term resuspension events on the oxidation of cadmium, lead, and zinc sulfide phases in anoxic estuarine sediments, Environ. Sci. Technol., 34(21), 4533-4537. doi:10.1021/es991440x

Sipos, P., Németh, T., Kis, V. K., and Mohai I., 2008. Sorption of copper, zinc and lead on soil mineral phases, Chemosphere, 73(4), 461-469.

https://doi.org/10.1016/j.chemosphere.2008.06.046

Viana, Z. P., Yin, K. and Rockne, K. J., 2008. Modeling Active Capping Efficacy. 1. Metal and Organometal Contaminated Sediment Remediation, Environ. Sci. Technol., 42, 8922-8929, doi: $10.1021 / \mathrm{es} 800942 \mathrm{t}$

Vijayaraghavan, K. and Raja F. D., 2015. Interaction of Vermiculite with $\mathrm{Pb}(\mathrm{II}), \mathrm{Cd}(\mathrm{II}), \mathrm{Cu}(\mathrm{II})$ and Ni(II) lons in Single and Quaternary Mixtures, CLEAN - Soil, Air, Water, 43(8), 1174-1180, doi: 10.1002/clen.201400423.

World Health Organization, 1996. Guidelines for drinking water quality, 2nd edn, vol 2: health criteria and other supporting information, 1996 (pp 940-949) and Addendum to vol 2. 1998 (pp 281-283), World Health Organization, Geneva.

World Health Organization, 2015. Guidelines for Drinking-Water Quality, Geneva: World Health Organization; 2011, Guidelines for Drinking-Water Quality, Geneva: World Health Organization; 2011.

Xu, M., He, Y., Wang, C., He, X., He, X., Liu, J., and Cui X., 2015. Preparation and characterization of a self-supporting inorganic membrane based on metakaolin-based geopolymers, Appl. Clay. Sci., 115, 254-259. https://doi.org/10.1016/j.clay.2015.03.019

Zhang, C., Zhu, M., Zeng, G., Yu, Z., Cui, F., Yang, Z., and Shen L., 2016. Active capping technology: a new environmental remediation of contaminated sediment, Environmental Science and Pollution Research, 23(5), 4370-4386. https://doi.org/10.1007/s11356-016-6076-8 
Zhang, Y. and Liu L., 2013. Fly ash-based geopolymer as a novel photocatalyst for degradation of dye from wastewater, Particuology, 11, 353-358. https://doi.org/10.1016/j.partic.2012.10.007

Zoumis, T., Schmidt, A., Grigorova, L., and Calmano W., 2001. Contaminants in sediments: remobilisation and demobilisation, Science of the Total Environment, 266(1), 195-202. https://doi.org/10.1016/S0048-9697(00)00740-3 